\title{
ANALYSIS OF SMALL BUSINESS ROLE IN THE ECONOMY OF UKRAINE IN GLOBALIZATION: PROBLEMS AND WAYS OF IMPROVEMENT
}

\section{АНАЛІЗ РОЛІ МАЛОГО БІЗНЕСУ В ЕКОНОМІЦІ УКРАЇНИ В УМОВАХ ГЛОБАЛІЗАЦІЇ: ПРОБЛЕМИ ТА ШЛЯХИ ВДОСКОНАЛЕННЯ}

\author{
Nikitina Alina \\ Candidate of Economic Sciences, Associate Professor, \\ Associate Professor at the Department of International Economics \\ and Management of FEA, \\ Kharkiv National Economic University named by Symon Kyznez
}

Abraimova Anna, Shalaieva Anastasiia students of the MEV faculty Kharkiv National Economic University named by Symon Kyznez

Нікітіна А.В. кандидат економічних наук, доцент, доцент касредри міжнародної економіки та менеджменту зовнішньоекономічної діяльності, Харківський національний економічний університет імені Семена Кузнеця

Абраімова А.М., Шалаєва А.М. студентки фракультету міжнародних економічних відносин, Харківський національний економічний університет імені Семена Кузнеця

In the result of scientific sources deep analysis of the small business in Ukraine the place and role of the small business and its current state in the economy of the country were determined. The structure of the small business complex was considered and the effective methods of improving this situation were determined in the current economic conditions of the country. The distribution of small business by the type of their economic activity was determined through the statistical analysis. The main factors which negatively affect and cease the development of small enterprises were outlined. The appropriate effective governmental and non-governmental ways of small business improvement were suggested. The factors that limit the opportunities for small business development in the international market were pointed out. The development potential of small enterprises was assessed and the order of improvement of the business climate of Ukraine was determined. The factors of attractiveness for investing in the Ukrainian small business sector were investigated and the ways to improve its condition were suggested.

Key words: small business, small enterprise, individual, profit, development, market, entrepreneurial activity, economy of Ukraine.

В результаті глибокого аналізу наукових джерел щодо малого бізнесу України були визначені місце і роль малого бізнесу і його сучасний стан в економіці країни. Розглянуто структуру комплексу малого бізнесу, визначені ефрективні методи поліпшення цієї ситуації в сучасних економічних умовах країни. Розподіл малих підприємств за видами економічної діяльності визначався шляхом статистичного аналізу показників малого підприємництва в Україні. Виділено основні фрактори, які негативно впливають і заважають становленню та розвитку малих підприємств. Були запропоновані та впорядковані відповідні ефекктивні урядові та неурядові шляхи поліпшення стану малого бізнесу. Виділено фрактори, що обмежують можливості розвитку малого бізнесу на міжнародному ринку. Був оцінений потенціал розвитку малих підприємств і визначено порядок поліпшення ділового клімату України. Були досліджені фрактори привабливості для інвестування в український сектор малого бізнесу і запропоновано шляхи покращення його стану. Актуальність даної теми полягає в важливості діяльності сектора малого бізнесу як рушійного фрактору розвитку сучасної ринкової 
економіки. На сьогоднішній стан сорера малого підприємництва в Україні є малорозвиненою, а будь-які спроби змінити цю ситуацію залишаються незавершеними або притиснуті законами, які вже не $\epsilon$ актуальними для сьогодення. 3 метою підняття рівня ефективності економіки України, були проведені спеціальні дослідження статистичних показників діяльності даного сектору економіки, зроблені відповідні висновки та розроблені пропозиції щодо поліпшення стану малого бізнесу. Зокрема були висвітлені сорери впливу малого підприємництва в економіці України, фрактори, що дестабілізують його діяльність, проблеми розвитку малого бізнесу в Україні, також були вказані урядові та неурядові способи вирішення несприятливої ситуації, що склалася в економічному просторі держави. Конкурентоспроможність держави прямо залежить від ступеня розвитку комплексу малого підприємництва, що впливає на структуру економіки, швидкість грошового обігу в державі та, відповідно, інвестиційну привабливість на міжнародному ринку.

Ключові слова: мале підприємництво, прибуток, розвиток, ринок, підприємницька діяльність, економіка України.

В результате глубокого анализа научных источников о малом бизнесе Украины были определены место и роль малого бизнеса и его современное состояние в экономике страны. Рассмотрена структура комплекса малого бизнеса, определены эфорективные методы улучшения этой ситуации в современных экономических условиях страны. Распределение малых предприятий по видам экономической деятельности определялось путем статистического анализа. Выделены основные фракторы, которые негативно влияют и мешают развитию малых предприятий. Были предложены соответствующие эфрфективные правительственные и неправительственные пути улучшения малого бизнеса. Выделены фракторы, ограничивающие возможности развития малого бизнеса на международном рынке. Был оценен потенциал развития малых предприятий и определен порядок улучшения делового климата Украины. Были исследованы фракторы привлекательности для инвестирования в украинский сектор малого бизнеса и предложены пути улучшения его состояния.

Ключевые слова: малое предпринимательство, прибыль, развитие, рынок, предпринимательская деятельность, экономика Украины.

Introduction. Small businesses are an integral part of a socio-economic state of the country. Firstly, they contribute to maintaining the stability of market relations, since a large part of the population is drawn into this system of relations, because the stability of the system can be provided when $20-30 \%$ of the citizens of the country have their own effective business. Secondly, they create the necessary mobility of production in the conditions of flexible market deepening of specialization and wide development of production cooperation without which its success is impossible. Ultimately, this leads to a dynamic economic development and growth of the national economy. Thirdly, the role of small enterprises in the activities of large and medium-sized enterprises is constantly increasing. Also great advantage of small businesses is the creation of new possibilities not only for employment but also for entrepreneurial activity of the population and the use of free production opportunities. That is why it is necessary to investigate this field.

Analysis of recent research and publications. The prospects of small business development in Ukraine were researched by the following national scientists: H.Ye. Havryliuk [1, p. 17-21], S.U. Abdybekov [2], D.S. Pokryshka [3], O.S. Ivanilov [4, p. 728], D.V. Vasylieva [5], O.I. Tymchenko [6] and others. They studied the role of small business in Ukrainian economy and defined different approaches for solving problems of small businesses functioning in current market conditions. However, the situation is changing over time, so that the issue of finding appropriate ways to improve the efficiency of small business in the Ukrainian economy needs to be further investigated.
Small business is an independent, systematic, proactive economic activity of small businesses and citizens-entrepreneurs (individuals) which is carried out at their own risk in order to gain profit. It is any activity (commercial, industrial, financial, innovative, insurance, etc.) of certain entities whose main purpose is to realize their own economic interest [5].

Small enterprise is an organizational and economic type of enterprises that are qualified by the number of employees with specified by activity, volume of fixed capital, annual turnover, etc.

Havryliuk H.Ye. [1, p. 17-21] believes that small business is a significant component of market economy of developed countries, a special, integral element of its inherent competitive mechanism. Having analyzed the data of the Ministry of Economic Development and Trade of Ukraine [7], among all the enterprises of our country, small and medium-sized businesses account for $99.8 \%$, provide $79 \%$ of workplaces and make up $16 \%$ of total exports in Gross Domestic Product for 2018.

Aim of the article is to analyze the role of small business particularly in the economy of Ukraine, reveal and systematize the problems that cease its development; to identify and systematize the ways of solving them in order to accelerate the economic development of the country.

Results. Small business is one of the main tools for the development of the national market economy. Historically this particular sector of the economy has become a necessary primary step to create the market environment in the form of small-scale production. Nowadays it is obvious 
that the prospect of competitive market establishment directly depends on how effective will be the realization of the small businesses potential in the country. As a role model in this process we can take rich experience of the leading countries of the world. At present in order to stimulate the development of small business in Ukraine, the government authorities have adopted and implemented the laws of Ukraine "On Development and State Support of Small and Medium Business in Ukraine", "On State Registration of Legal Entities and Entrepreneurs - to Simplify Registration of Individuals as Taxpayers", "On the National Program on Promotion of Development of Small Business in Ukraine", "On the Establishment of Territorial Bodies of the State Service for Regulatory Policy and Business Development", The Cabinet of Ministers of Ukraine Order "On Approval of the Concept of the National Program of small and medium enterprises in the years 2014-2024" [8] special programs were directed to support small and medium enterprises.

After the analysis of the scientific sources, it was found that small business in Ukraine contributes to the development of the country's economy and has significant advantages over the activities of large enterprises such as:

- it restructures the economy of the country and assimilates it to high-developed countries, where the majority of GDP is made up of small and medium enterprises (from 30\% up to 60\%);

- it is quicker in responding to changes in the market, provides the economy of the state with the necessary flexibility to general processes in society, ensures the existence and maintenance of fair competition and fills the market with goods and services that are in demand for a certain period, providing a rapid cost recovery;

- it is one of the main tools to overcome market monopolization. Given the narrow specialization and use of advanced technology to increase its competitiveness small business undermines the monopoly position of large corporations;

- it is more likely to create more workplaces and absorb excess labor during cyclical downturns or structural changes in the economy. In economically developed countries from $50 \%$ up to $70-80 \%$ of all workplaces are on average created by the small businesses;

- it is the driving force behind the development of scientific progress. In order to always stay relevant to the consumer, small business is trying to implement the latest technologies, thereby providing a significant impetus and financial incentive to develop new business ideas;

- it plays an important role in reducing the differentiation of society by material status, relieves social tension and democratizes market relations because it is the basis for the creation of the middle class. The formation of this particular section of the population is an important component for the stable development of the state's economy. Exactly the middle class is financially and socially ready to be responsible for this process;

- it affects the overall recovery of the economy and society as a whole by creating the skills of doing their own business, the success of which depends on the professionalism and willingness of the entrepreneur to take risks.

Having analyzed the results we have found that small-scale business takes enormous $99 \%$ of all enterprises and natural entrepreneurship entities in Ukraine (Figure 1) [9].

Most of them are small entrepreneurship entities. The reason may lay in the fact of easier registration of such type of economic entity and their mobility and flexibility. This diagram illustrates the importance of small business and the necessity of its development and support from the government. In order to estimate situation we need to compare the data to the same indicators in different developed countries. For example, in the USA small business takes $97.6 \%$ of all enterprises, in Japan this indicator is $99.2 \%$, Germany is $99.3 \%$, Great Britain is $99.1 \%$, and Singapore is $98.5 \%$. We see that all of those well-developed countries have the share of small business from all economic entities in their economy exceeds 90\%. After providing analysis of the data, we can claim that Ukraine is quite well-developed according to this indicator. Since small business contributes to overcoming monopoly in the national economy and stimulates competition, which is an important part of market economy, huge part of it in the economy of Ukraine should signify big level of competitiveness. However, from the Global Competitiveness report [10] we see that it is not the case. In 2019 Ukraine was on 85th place out of 141 with the score 57 out of 100 , what is even less than in 2018 by 2 places. In 2018 the country was on 83rd place with the same score, while the USA takes the 1st place with score 85.6, Germany was on the 3rd with 82.8 and Singapore was on the 2nd place with 83.5 points. The methodology used in this scientific report is trustful and used by lots of economists, so the reason for such inconsistency may lay not in the number of small business, but in the volume of product they produce.

According to the latest data small and medium businesses in Ukraine bring $55 \%$ of gross domestic product (GDP) to the economy of the country and if taking into account only small business, then it is only $16 \%$ of GDP. According to the World Trade Report [11], the median GDP contribution of Small and Medium-sized Enteprises' (SME) is roughly 45\%. According to the United Nations, in general, 30 to $60 \%$ of the national product is produced by SMEs, depending on the country, it means that the situation on the Ukrainian market is normal. However, the problem of small competitiveness in Ukraine is not well-studied, but the main are the technological backwards and unfavorable business climate.

The Ukrainian economy has an unfavorable climate to create and support the sustainable development of small businesses. This can be seen 


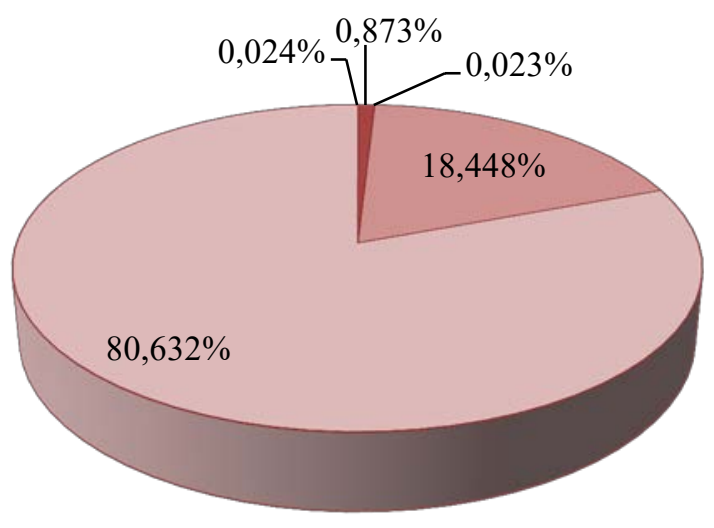

\author{
large enterprises \\ $\square$ medium enterprises \\ $\square$ middle-size entrepreneurship \\ entities \\ $\square$ small-scale enterprises \\ $\square$ small entrepreneurship \\ entities
}

Figure 1. Economic structure of Ukraine by the share of small, medium and large business

from the distribution of small enterprises by the type of their economic activity (Figure 2) [12].

It is illustrated that wholesale and retail trade is the sector of economy which has the biggest part of small business. But industry, which includes mining and quarrying, manufacturing, electricity, gas, steam and air conditioning supply and water supply, sewerage, waste management and remediation, takes only around $6 \%$. Moreover, the sphere of agriculture, forestry and fishing is poorly developed in Ukraine, only $3 \%$ of all small enterprises work in this sphere. It is a huge surprise, since Ukraine has a huge agricultural potential and according to the aims of the United Nation, the productivity of agriculture and the incomes of small food producers will be doubled in Ukraine by 2030 [13]. Modern sector of information and communication is quite popular among small business; around $10 \%$ of all small enterprises contribute to it. However, it is important to notice which spheres do not involve a lot of small entrepreneurs. They are financial and insurance activities, education, human health and social work activities, arts, entertainment and recreation, administrative and support service activities, construction.

In order to carry out full analyzes of structural distribution of small business, it is necessary to

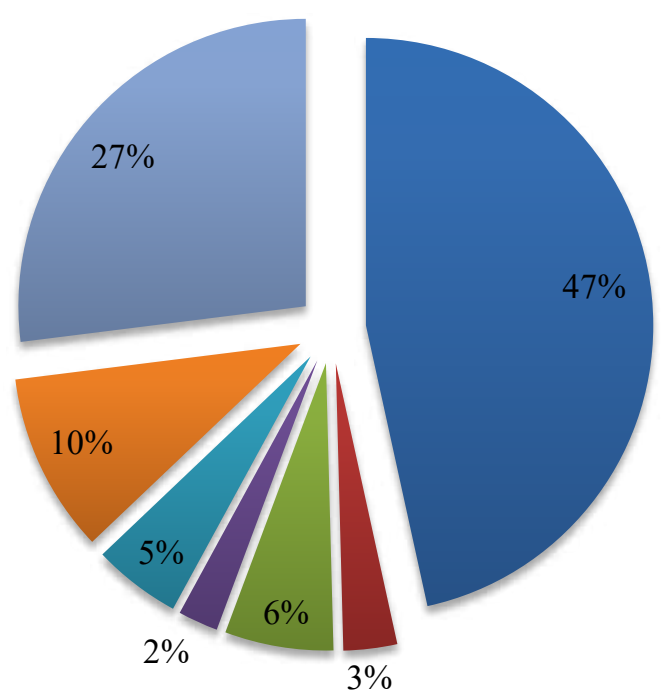

\author{
Wholesale and retail trade; repair of \\ motor vehicles and motomotorcycles \\ Agriculture, forestry and fishing \\ - Industry \\ Construction \\ Transportation and storage \\ Information and communication \\ Other service activities \\ (Accommodation, food, support \\ services, finance, education, social \\ work, entertainment, etc.)
}

Figure 2. The distribution of small business by the type of their economic activity 
compare the data on Ukraine by the same data of other countries. Since Ukraine lies between Europe and Asia, it is reasonable to compare it to those two types of economies: European and Asian [2].

In Europe agriculture engages $11 \%$ of all small enterprises, industry - 18\%, wholesale and trade $-21 \%$, transportation $-14 \%$ and construction $-13 \%$. As we can see the European model is balanced enough. Although sales still take the largest part, the difference between this branch and other spheres is not so huge. In Asia the situation is rather different. Large part of small business is engaged into industry: $41 \%$. Agriculture is also bigger with $21 \%$, construction is a bit less than in Europe with $10 \%$, and so is transport with $12 \%$. However, wholesale and trade take only $16 \%$ of small business. Other sectors of economy do not involve small business or its share is insignificant.

According to the data, small business distribution on different branches of the economy in Ukraine is more similar to the European model, although a lot of work should be done in order to take it to harmonize it. Participants in small business activity in Ukraine do not give preferences to industry. However, the share of industry in Ukraine is still much lower than one in Europe and so do agriculture, transportation and construction. At the same time wholesales and trade engage too many small entities, much more than even in Europe. But the main feature that distinguishes the Ukrainian economy is that small business is actively involved into lots of various spheres, such as accommodation and food, information and communication, financial and insurance, real estate activities, scientific and technical activities, administrative service activities, education, health and social work, arts, entertainment and other service activities, which engage around $37 \%$ of all small enterprises.

The most obvious reason for such branch distribution is that wholesale and retail sale enterprises do not need significant investment for being set up and have fast money circulation. It is the easiest way to earn money. That means that surviving for a small enterprise without fast money circulation is still extremely difficult in Ukraine. Indeed, the existence of small enterprises being economically active is tiny. Most of them work only for 1-2 years. Although in 2018 Financial Times Ukraine was defined the first of all post-Soviet states that managed to improve its business climate, 9 out of 10 new companies in Ukraine fail [14]. That is why it is extremely important to understand and analyze the causes of small business failure.

We have identified the main factors of small business weakness and instability:

- general macroeconomic indicators of the Ukrainian economy. Small business, as a structural unit of the state's economy, directly responds to both positive and negative dynamics of the country's main macroeconomic indicators;

- policy of the government. First of all, even though the government has approved "The Strat- egy for the Development of Small and Medium-Sized Entrepreneurship in Ukraine for the period up to 2020", the actions taken were not enough. One of the main tools to support SMEs is financial assistance in the form of available loans. However, in Ukraine interest rates on business loans are too high and reach around 20-21\% per year. To compare, in the USA and Germany money can be borrowed at the interest rate of $2-4 \%$. High cost of loans makes it impossible to attract them for business development. Only $10 \%$ of enterprises in Ukraine are able to use loans [15];

- high tax rates for small businesses. Entrepreneurs become unable to pay statutory taxes because they do not receive the expected profits. In one case, a small business simply stops its activity because of unprofitability. Otherwise, this situation forces many small business entities to hide their income in order to pay less tax; as a result, they resort to the shadow economy.

- lack of favorable regulatory and legal support for the development of small business, as well as entrepreneurship as a whole. There is a lack of clear regulation of relations between business entities and authorities; there is no effective legislative mechanism for state financial support for small businesses. As a result, entrepreneurs have no incentive to start their own business;

- limited financial and material resources. There are insufficient support of small business and lack of satisfactory level of machinery, even though there is significant innovation potential. In the absence of a sufficient amount of start-up capital, own production facilities and equipment, many small businesses do not start their activity, even though their business plan is perspective;

- lack of education. Lots of entrepreneurs are lack of business education. They do not know how to set up business nowadays, how to create a product or service that will attract customers and how to promote their product on markets. That leads to bad management decisions, which further worsen production optimization and lead to decrease in profit. They try to combine several activities within one small company, and the result is usually the decrease of effectiveness.

- lack of reliable information. Imperfect accounting and statistical reporting of small businesses; limited information about the market situation, advisory support and business-educational programs do not give possibility for an individual to get interested in his business.

- business monopolization. Today the displacement of small businesses from the general market by big business monopolies is a very common phenomenon in the Ukrainian economy. Monopolies deprive entrepreneurs of the opportunity to develop an area that dynamically responds to all the changes in the market;

- low competition in domestic markets. It is very difficult for new businesses to survive and form their competitiveness in the Ukrainian market, as 
there is a tendency of high concentration of firms in certain sectors of the economy;

- instability of business conditions (high level of corruption, bureaucracy, raiding). Changes in regulatory and economic policies makes entrepreneurs apply shadow economy schemes for getting profit. That situation causes up to $60 \%$ of capital outflow, closing production and stopping activity. Ukraine is a country where entrepreneurship requires a high degree of risk and lots of informal costs.

Also the mentioned above problems of small business development include many unnecessary formal documentation, references, permits, licenses and regulations; old technical standards; corrupted, ineffective examinations with Soviet features; inconsistent implementation of the rules; weak protection of property rights.

Moreover in order to grow it is necessary for business to have access to the international market. Unfortunately, small business in Ukraine has really low export opportunities. While 47\% of large enterprises perform export activity, only around $12 \%$ of small ones participate in international market. They export only $4 \%$ of their products, while as for large companies this indicator is 4 times bigger. The factors that limit the opportunities for small business, according to Pokryshka D.S. [3], are:

- unreasonable difficulties in time and money for them to pass customs procedures. It takes 96 hours for Ukrainian exporter to draw up documents, while in the European Union companies spend only 1-3 hours on paperwork;

- limited access to the information about the situation on international market;

- lack of qualification for managing international activity;

- legislative flaws in regulating mechanisms of procedures and requirements in conducting foreign trade operations;

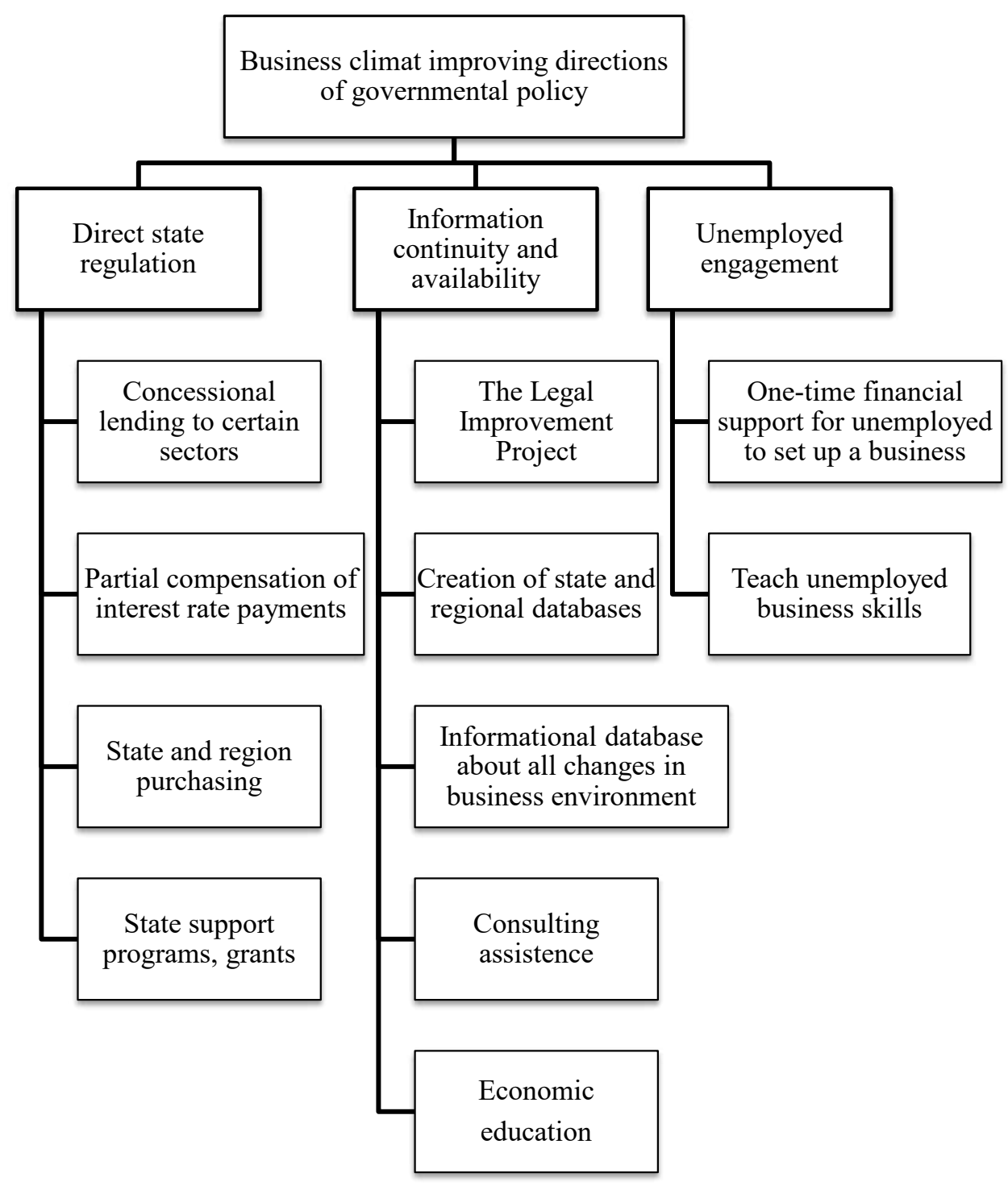

Figure 3. Directions of governmental polity aimed to improve the Ukrainian business climate 
- low competitiveness of small business because of the lack of investments for technological modernization and motivation for implanting innovations;

- insufficient effectiveness of state programs for export supporting;

- existence of language and cultural barriers.

All those problems show the necessity to create business climate favorable for small enterprises' development on the state level. Small business is the main factor for increasing the efficiency of state's economic potential and competitiveness realization, its stable formation in the international division of labor. Therefore, the issue of solving the problems of small business creation and development in Ukraine should be one of the most important directions of state economic policy. In order to deepen the formation of conditions for market reforms, the Verkhovna Rada adopted a program of state support for small business, which outlined directions for improving market infrastructure, such as: assistance in the preparation of staffing system; implementation and simplification of taxation system; improvement of accounting and reporting system for small businesses; financial support for small businesses; realization by small enterprises of scientific, economic, social, projects; public procurement to stimulate the production process of small businesses [4, p. 728].

After analysis, we have distinguished 3 main governmental policy directions, which should be aimed at the Ukrainian business climate improving (Figure 3).

But in our opinion, in addition to the state stimulation of small business development there are many other factors that can positively affect the effectiveness of small business activity in Ukraine. (Figure 4).

Both factors are important for the economy, but only combining the powers of governmental and non-governmental ways to improve the role of small business can change the situation to the better. Systematic approach is necessary in order to achieve the best outcome in the shortest terms.

Conclusion. Small business is an essential part of the Ukrainian economy and is extremely important for its development. It plays an important role in increasing the flexibility of the market, overcoming monopolization, employing the population, creating the middle class necessary for the country's democratization and implementing the achievements of the scientific progress. In Ukraine, as in

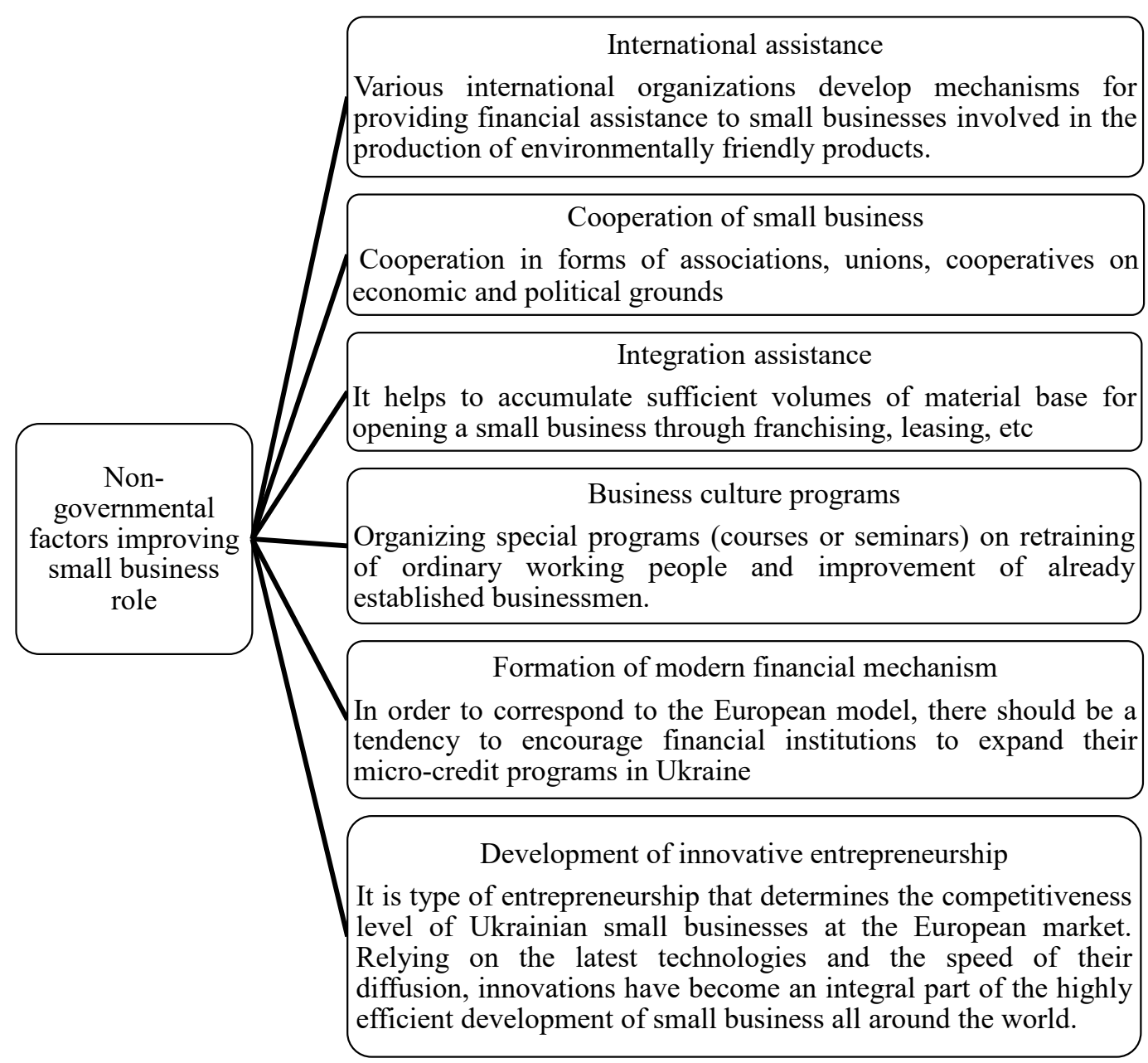

Figure 4. Non-governmental factors which improve the role of small business 
all the developed countries, small business takes the absolute majority of all economic entities and contributes well to GDP. However, that does not improve the competitiveness on the Ukrainian market because of several problems in the economy. The biggest share of small business is engaged into wholesale and retail trade, but only little part of it does agricultural and industrial activity, although informational sphere is well-developed. Having compared the structure of small business by their economic activity, we came to the solution that Ukraine is closer to the European model of small business distribution, although a lot of work should be done in order to harmonize the market. We have distinguished the problems that worsen the conditions for small business flourishing and after their analysis we have identified possible solutions as the necessary steps from both the governmental and non-governmental sphere. In order to promote small business the governmental policy should support certain sectors of economy, partially compensate the interest rate payments and increase money flows into the small business by supporting programs. Priority directions for future scientific researches should be theoretical substantiation of development of cooperation of small business entities with international organizations and business structures, which in turn should promote innovation and scientific and technical small business development, legal bases for one-time payment to the unemployed for setting up their business, trust-issues to small enterprises and economic benefits of partial compensation of interest rate payment to opening small business by the government.

\section{REFERENCES:}

1. Геєць В.М. Інноваційні перспективи України. Харків : Константа, 2006. 272 с.

2. Данилишин Б.М., Корецький М.Х., Дацій Н.В. Макроекономічне регулювання інвестиційних процесів : монографрія. Ніжин : Аспект-Поліграф, 2007. 204 с.

3. Кравців В.С., Мельник М.І., Антонов В.Б. Залучення прямих іноземних інвестицій в економіку України: проблеми та політика активізації : монографрія. Львів : ІРД НАН України, 2011. 386 с.

4. Лугова М.С. Реформування інвестиційної політики у контексті європейської інтеграції. Науковий вісник Східноєвропейського національного університету імені Лесі Українки. Міжнародні відносини. 2013. № 10. C. 264-268. URL: http://nbuv.gov.ua/UJRN/Nvvnum_2013_10_39 (дата звернення: 21.11.2019).

5. Мальський М.3. Інвестиційна політика в Європейському Союзі та перспективи для України. Науковий вісник Дипломатичної академії України. Серія «Економічні науки». 2016. Вип. 23. Ч. 3. С. $114-121$. URL: http://nbuv.gov.ua/UJRN/Nvdau_2016_23(3)_15 (дата звернення: 21.11.2019).

6. Зовнішньоекономічна діяльність / Державна служба статистики України. URL: https://ukrstat.org/ua (дата звернення: 22.11.2019).

7. Дудчик О.Ю. Інвестиційна привабливість України. Науковий вісник Мукачівського державного університету. Серія «Економіка та суспільство». 2016. № 2. C. 541-548. URL: http://biblio.umsf.dp.ua/jspui/ handle/123456789/2066 (дата звернення: 22.11.2019).

\section{БІБЛІОГРАФІЧНИЙ СПИСОК:}

1. Geyets V.M. (2006) Innovatsiini perspektyvy Ukrainy [Innovative prospects of Ukraine]. Charkiw: Constant. (in Ukrainian)

2. Danylyshyn B.M., Koretsky M.Kh. Datsy N.V. (2007) Makroekonomichne rehuliuvannia investytsiinykh protsesiv [The macroeconomic regulation of investment processes]. Nizhin: Aspect-Polygraph . (in Ukrainian)

3. Kravtsov V.S., Melnyk M.I., Antonov V.B. (2011) Zaluchennia priamykh inozemnykh investytsii v ekonomiku Ukrainy: problemy ta polityka aktyvizatsii [Attracting Foreign Direct Investment into the Ukrainian Economy: problems and Activation Policy]. Lviv: IRD NAS of Ukraine. (in Ukrainian)

4. Lugova M.S. (2013) Reformuvannia investytsiinoi polityky u konteksti yevropeiskoi intehratsii [Reforming investment policy in the context of European integration ]. Scientific Bulletin of Lesya Ukrainka Eastern European National University. International relations, vol. 10, pp. 264-268. Available at: http://nbuv.gov.ua/UJRN/ Nvvnum_2013_10_39 (accessed 21 November 2019).

5. Malskyy M.Z. (2016) Investytsiina polityka v Yevropeiskomu Soiuzi ta perspektyvy dlia Ukrainy [Investment Policy in the European Union and Prospects for Ukraine Avaliable at]. Scientific Bulletin of the Diplomatic Academy of Ukraine. Economic Sciences Series, vol. 23, pp. 114-121. Available at: http://nbuv.gov.ua/UJRN/ Nvdau 2016 23(3) 15 (accessed 21 November 2019).

6. Derzhavna sluzhba statystyky Ukrainy (2018) Zovnishnoekonomichna diialnist [Foreign Economic Activity], Kyiv: Informatsiino-analitychne ahentstvo (accessed 22 November 2019).

7. Dudchik O.Yu. (2016) Investytsiina pryvablyvist Ukrainy [Investment attractiveness of Ukraine]. Scientific Bulletin of Mukachevo State University. Series "Economics and Society", vol. 2, pp. 541-548. Available at: http://biblio.umsf.dp.ua/jspui/handle/123456789/2066 (accessed 22 November 2019). 